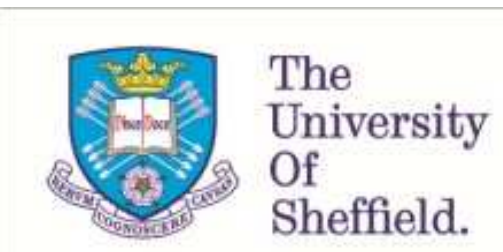

This is a repository copy of 'Dissonance of speech, consonance of meaning': The 862 Council of Aachen and the transmission of Carolingian conciliar records.

White Rose Research Online URL for this paper:

http://eprints.whiterose.ac.uk/125351/

Version: Accepted Version

\title{
Book Section:
}

West, C. orcid.org/0000-0001-9134-261X (2018) 'Dissonance of speech, consonance of meaning': The 862 Council of Aachen and the transmission of Carolingian conciliar records. In: Screen, E. and West, C., (eds.) Writing the Early Medieval West. Cambridge University Press , pp. 169-182. ISBN 9781108182386

https://doi.org/10.1017/9781108182386.012

This material has been published in Writing the Early Medieval West edited by E. Screen \& C. West. This version is free to view and download for personal use only. Not for re-distribution, re-sale or use in derivative works. (c) Cambridge University Press.

\section{Reuse}

Items deposited in White Rose Research Online are protected by copyright, with all rights reserved unless indicated otherwise. They may be downloaded and/or printed for private study, or other acts as permitted by national copyright laws. The publisher or other rights holders may allow further reproduction and re-use of the full text version. This is indicated by the licence information on the White Rose Research Online record for the item.

\section{Takedown}

If you consider content in White Rose Research Online to be in breach of UK law, please notify us by emailing eprints@whiterose.ac.uk including the URL of the record and the reason for the withdrawal request. 


\section{1. 'Dissonance of Speech, Consonance of Meaning': the 862 Council of Aachen and the transmission of Carolingian conciliar records}

Charles West

On 29 April 862, eight bishops gathered in the palace of Aachen to discuss the marriage of King Lothar II (ruled 855-869) and Queen Theutberga, and whether it should be ended. ${ }^{1}$ Although Lothar's attempt in 858 to free himself from his wife through a trial by ordeal had been an embarrassing failure, and despite a sceptical wider response to earlier councils in 860 which had laid the foundations for his case - a scepticism publicly voiced above all by Archbishop Hincmar of Rheims (d. 882) - Lothar was determined to press ahead. ${ }^{2}$ The bishops assembled in Aachen by the king therefore discussed the issue once again, and concluded that his marriage to Theutberga was now definitively over. This left Lothar free to marry his long-standing mistress Waldrada, which he duly did later the same year, little aware of the torrid times to come. ${ }^{3}$

We owe our knowledge of the decisions of the Aachen 862 council to the care its participants took to provide a written record of their meeting. As we shall see, that care was in itself far from unusual. What is less common, however, is that there survive not one but two separate accounts of the council. Moreover, one of the two texts both acknowledges and attempts to account for the duplication:

It was commanded to two of our brothers separately to entrust to writing this chain of reasoning, which with the Lord's inspiration we all together discovered. When each of

\footnotetext{
${ }^{1}$ Both the research and the writing of this chapter were made possible by a Humboldt-Stiftung fellowship, held at the Eberhard Karls Universität Tübingen and graciously hosted by Steffen Patzold. I owe thanks to audiences in Berlin and in Leeds for comments on early versions, to Rosamond McKitterick, Andreas Öffner, Warren Pezé and Graeme Ward for discussion of a draft, and to the MGH library in Munich for providing access to its microfilm collection. Due to constraints of space, notes have been pared to a minimum.

${ }^{2}$ For Hincmar's involvement, see R. Stone and C. West, trans., The Divorce of King Lothar and Queen Theutberga. Hincmar of Rheims's De Divortio (Manchester, 2016).

${ }^{3}$ A detailed summary of the case is provided by K. Heidecker, The Divorce of King Lothar II: Christian Marriage and Political Power in the Carolingian World (Ithaca, 2010).
} 
them presented his text to the holy council in the early morning after the night, our whole company praised it as filled with a wonderful appropriateness of meaning, and we thanked the Lord for the concordant opinion (sententia). And so we decided to add this, that if the tenor of one of the texts, discrepant in words, reaches anyone's hands, let him not be disturbed by the dissonance of speech, but rather be compelled to trust by the consonance of meaning. ${ }^{4}$

This chapter explores the implications of this double record for our understanding of the conciliar documents produced by the Frankish church under the Carolingians, the topic of Rosamond McKitterick's first book, as well as for the politics of a Frankish kingdom ruled by a Carolingian king, the topic of her second, with particular attention to the manuscript transmission of texts, a kind of evidence whose sheer indispensability for early medieval historians none has better demonstrated than McKitterick. $^{5}$

\section{Carolingian councils and their records}

The increase in the number and sophistication of conciliar records in various forms - decrees, minutes and charters - is something of a hallmark of the Frankish church under the Carolingian rulers, especially from the rule of Louis the Pious (814-40), when councils began to legislate independently of the king. ${ }^{6}$ The regular recourse of bishops in this period not only to collective decision-making but also to parchment to preserve those decisions stands in

\footnotetext{
4 'Huius series rationis in commune a nobis domino inspirante reperta duobus ex nostris fratribus litteris sequestratim commendari iniunctum est. Quod nocturno autem tempore primo mane sacro concilio uterque scripturam suam praesentavit, et mira sensuum convenientia redolentem omnis coetus noster collaudavit et de concordi sententia domino gratias egit, quod ideo subiciendum censuimus, ne, si alterius scripturae tenor in verbis discrepans in cuiuslibet manus devenerit, non moveatur de dissonantia sermonum, quem fidem accommodare compellit consonantia sensuum': Concilia Karolini Aevi IV, ed. W. Hartmann, MGH (Hanover, 1998), p. 78. A complete English translation of the two versions can be found at http://hincmar.blogspot.com (accessed November 2016).

${ }^{5}$ R. McKitterick, The Frankish Church and the Carolingian Reforms, 789-895 (London, 1977), esp. pp. 11-44; R. McKitterick, The Frankish Kingdoms under the Carolingians (London, 1983), esp. pp.178-79.

${ }^{6}$ W. Hartmann, Die Synoden der Karolingerzeit im Frankreich und in Italien (Paderborn, 1989): see pp. 11-27 for a summary of the textual transmission.
} 
contrast to their predecessors under the last Merovingian kings, and even more sharply to their tenth-century successors. It is a measure not only of the confidence that Frankish bishops had in the written word, but also of the significance they attributed to their collective resolutions, which they deemed worth handing down to posterity alongside the sacred councils of Late Antiquity. Not all Frankish clerics approved of this conciliar energy. The forgers responsible for the Pseudo-Isidorian decretals promoted instead a view that subordinated even the early church councils to papal decree, revising the acts of the venerable council of Chalcedon (451) in this direction. ${ }^{7}$ But this dissent remained the opinion of a minority, however vociferous.

Much like annals, the records of Frankish councils may seem straightforward accounts simply of what happened. Again like annals, however, they are more complex and constructed texts than they appear. The general absence of references to liturgical activity is a reminder that they were not verbatim accounts of proceedings. ${ }^{8}$ Behind every record of a Frankish council, there stands an author who had to make choices in how best to represent discussion: what to put in, and above all what to leave out. As anyone who has taken minutes will know, this is not straightforward at the best of times, and Carolingian synods could be contentious. Notaries may have been tasked with taking notes during the council, as they certainly were in 829 and as was normal in Late Antiquity, but the final redaction of the decisions was a delicate matter best undertaken by a bishop or senior cleric. ${ }^{9}$ In a few cases, we have a good idea of who that cleric was. We know for instance that Abbot Lupus of Ferrières was responsible for writing the decisions taken at the council of Ver in 844 because

\footnotetext{
${ }^{7}$ K. Zechiel-Eckes, 'Verecundus oder Pseudoisidor? Zur Genese der Excerptiones de gestis Chalcedonensis concilii', Deutsches Archiv 56 (2000), 413-46; more generally, C. Harder, Pseudoisidor und das Papsttum: Funktion und Bedeutung des apostolischen Stuhls in den pseudoisidorischen Fälschungen (Cologne, 2014).

${ }^{8}$ R. McKitterick, 'Constructing the past in the early Middle Ages: the case of the Royal Frankish Annals', Transactions of the Royal Historical Society 7 (1997), 101-29. See also now R. Kramer, 'Order in the Church: Understanding Councils and Performing Ordines in the Carolingian World', Early Medieval Europe, forthcoming 2017.

${ }^{9}$ Concilia Karolini Aevi II/ii, MGH, ed. Werminghoff, p. 600. Notaries are also mentioned in several redactions of the Ordo de celebrando concilio, ed. H. Schneider (Hanover, 1996), e.g. the very popular Ordo II at p. 177.
} 
he said so, while Bishop Jonas of Orléans probably had a hand in redacting the written records of councils in $825,829,835$ and maybe $836 .^{10}$

Perhaps the most prolific conciliar author was Archbishop Hincmar of Rheims, responsible for the records of several councils including Soissons 853, Soissons 866, Douzy 871, Troyes 878 and Fismes 881 . Hincmar was also an innovator, who seems to have introduced to Francia the textual technique of dividing councils into sittings (actiones) and recording the minutes of each one. ${ }^{11}$ Though common in Late Antiquity, this was not a Frankish literary tradition before the ninth century. But Frankish clerics were keenly interested in late antique councils as authoritative records of the past - indeed many of the most important, such as Carthage 411, Chalcedon 451 and the Lateran council of 649, survive only or largely through manuscripts made by Carolingian scribes - and it is likely that Hincmar was deliberately modelling his new style of record, and perhaps the choreography of the council itself, on late antique or Roman precedent to enhance its authority. ${ }^{12}$ It is a good illustration of the room for manoeuvre that authors of conciliar texts enjoyed in shaping how meetings were represented on parchment.

The trust that could be placed in the written record of a council, and its legitimacy as a historical record, accordingly depended on two conditions: that the author had accurately represented the discussion and the outcomes, and that the agreed-upon text had been faithfully transmitted. Frankish bishops were anxious about both these issues. For instance, Hincmar of Rheims expressed concerns about the false attribution of decisions to councils, both in the recent past, for example the Council of Tusey in 860, and those held in Late

\footnotetext{
${ }^{10}$ Lupus of Ferrières, Epistolae, 'capitula meo stilo tunc comprehensa', ed. and tr. L. Levillain, Loup de Ferrières: Correspondence (Paris, 1964), vol. I, p. 182 (based on Paris, BnF. Ms Lat. 2858, fol. 25r); A. Dubreucq, ed. and tr., Jonas d'Orléans. Métier du roi (Paris, 1995), pp. 18-23.

${ }^{11}$ Hartmann, Synoden, p. 6; W. Hartmann, 'Original und Rekonstruktion eines Archetyps bei den spätkarolingischen Konzilsakten', in Vom Nutzen des Edierens, ed. B. Mertens, A. Sommerlechner and H. Weigl (Vienna, 2005), pp. 77-90.

${ }^{12}$ On the Frankish interest in the Late Antique past, and in councils as records of that past, see R. McKitterick, History and Memory in the Carolingian World (Cambridge, 2004), esp. pp. 249-256. Hincmar may have been specifically inspired by the Roman council of 769, on which see R. McKitterick, 'The damnatio memoriae of Pope Constantine II (767-768)', in Ross Balzaretti, Julia Barrow and Patricia Skinner (eds), Italy and Medieval Europe (Oxford, forthcoming).
} 
Antiquity, notably the Council of Nicaea in $325 .{ }^{13}$ And in the Annals of St-Bertin, he accused Archbishop Ansegis of Sens of writing a report that deliberately misrepresented the decisions of the 876 council of Ponthion. ${ }^{14}$ Hincmar's suspicions may have been based on first-hand experience, since he was himself accused of the tendentious redaction of conciliar acts. ${ }^{15}$ Far from working in the oral culture that historians used to imagine characterised the early Middle Ages, one of the challenges facing the Frankish Church in the ninth century was the proliferation of misleading documents: a problem not of too few texts, but of too many. It was in response to such concerns that strategies were deployed to guarantee the fidelity and authenticity of conciliar records. From the mid ninth century, it became usual for Frankish bishops to sign the record of councils, whether redacted as canons or as minutes. ${ }^{16}$ This again was a common practice in Late Antiquity - it was part of the standard conciliar liturgy - but had apparently lapsed in Merovingian and early Carolingian Francia. ${ }^{17}$ Adding one's signature was in part a matter of indicating personal adherence to the collective decision, but we may suppose that it also served to validate the record itself. That was presumably why the scribes who compiled the copy of the Council of Trosly in 909, now Vatican Biblioteca Apostolica, Reg. Lat. 418, took care to imitate the signatures of the bishops who participated: a technique paralleled in the treatment of some charter witness lists. ${ }^{18}$

Secondly, it was obviously essential to ensure that only one version of a council's decision was produced, rather than competing alternative versions. Exactly how that record was then disseminated remains something of a mystery: perhaps participants were provided with a booklet after the council ended, or perhaps they brought their own scribes. Whatever

\footnotetext{
${ }^{13}$ Hincmar of Rheims, Opusculum LV Capitulorum, in Die Streitschriften Hinkmars von Reims und Hinkmars von Laon, 869-871, ed. R. Schieffer (Hanover, 2003), pp. 226-7; on Tusey, see W. Hartmann, 'Unterschriftslisten karolingischer Synoden', Annuarium Historiae Conciliorum 14 (1982), 124-39, esp. 134-9.

${ }^{14}$ Annales Bertiniani, ed. F. Grat (Paris, 1964), p. 205, 'sine conscientia synodi dictata'; see Concilia Karolini Aevi V, ed. W. Hartmann, I. Schröder and G. Schmitz (Hanover, 2012), pp. 52-4.

${ }^{15}$ MGH Epistolae Karolini Aevi IV, ed. E. Perels (Berlin, 1925), pp. 414-22.

${ }^{16}$ Hartmann, 'Unterschriftslisten'.

${ }^{17}$ Ordo, ed. Schneider, p. 183: Hincmar of Rheims may have known this text.

${ }^{18}$ G. Schmitz, 'Das Konzil von Trosly 909: Überlieferung und Quellen', Deutsches Archiv 33 (1977), 341-434; on 'Pseudoautographie', see M. Mersiowsky, Die Urkunde in der Karolingerzeit. Originale, Urkundenpraxis und politische Kommunikation (Wiesbaden, 2015), esp. pp. 810-11.
} 
mechanisms there were, the reproduction processes were not perfect, since it is possible to spot differences in the textual witnesses to almost any council that survives in more than one manuscript. ${ }^{19}$ Still, these differences were generally minor. And even when more substantial revisions are evident, they still form a single textual transmission (with the possible and partial exception of the Council of Tribur in 895). ${ }^{20}$ No matter how the text's reproduction was arranged, the consequence was that for most Carolingian councils we have multiple variants of a single account, not competing independent ones.

Given that Frankish church councils could be large-scale affairs, with dozens or even hundreds of literate clerics present, this level of success in limiting textual proliferation is impressive. But contemporaries would have understood perfectly well that it was important to demonstrate consensus in this way. After all, a canon law collection compiled in the ninth century observed (in line with earlier traditions) that common intent was really the underlying meaning of the word council, and concluded that 'those who disagree amongst themselves are not having a council, since they do not think as one' ${ }^{21}$

\section{The two accounts of Aachen 862 and their authors}

This is what makes the double accounts of the 862 Council of Aachen, labelled in the MGH edition as Text $\mathrm{A}$ and Text $\mathrm{C}$, so remarkable. Neither account directly contradicts the other; they cite most of the same authorities; both of them argue that Queen Theutberga's proven incest makes it impossible for her to be married any longer to King Lothar II. The alreadyquoted statement of one of these accounts, that they are essentially compatible, is therefore not entirely groundless. Nevertheless, neither is copied from the other, and there are some

\footnotetext{
${ }^{19}$ Hartmann, 'Original und Rekonstruktion'.

${ }^{20}$ On the bewildering transmission of this council, see Concilia Karolini Aevi V, ed. Hartmann et al., pp. 319-22, which concludes however that two of the three versions are probably edited variants of the third (the Collectio Diessensis-Coloniensis). On the editorial challenges of coping with the textual variants, see Hartmann, 'Original und Rekonstruktion'.

21 'Concilium vero nomen tractum ex communi intentione, eo quod in unum dirigant omnes mentis obtutum.... Unde et qui sibimet dissentiunt, non agunt concilium, quia non sentiunt unum', from the Hispana Gallica Augustodunensis, transcribed by Annette Grabowsky at http://www.benedictus.mgh.de/quellen/chga/chga_006t.htm (accessed November 2016) the older canon law collection, the Hispana, has a similar text, ultimately adapted from Isidore of Seville, Etymologiae VI, xvi. The Hispana was consulted at the 862 Aachen council.
} 
clear variations between them both in tone and in how they present the meeting that point to separate authorship.

The version known as Text A frames the council as having been called by Lothar II explicitly in order to advise him: the bishops are therefore acting in response and in concert with the king. They urge the king to live up to his office, a commitment to which he agrees before he brings up the issue of his marriage. That the king has already done penance for his illicit relationship with Waldrada is stressed, and Archbishop Theutgaud of Trier is named as a witness to it. Finally, three authorities - the 546 Council of Lerida (from the seventh-century Hispana canon law collection), Ambrosiaster's Commentary on Paul, and a statement attributed to the 506 Council of Agde (also from the Hispana) - are briskly cited in succession to show that the marriage is now over, and that the king can remarry.

The version edited as Text $C$ in contrast makes the council seem a little more active. It is not specified that the king had convoked it, and the council is already in session when the case of his marriage is brought up. That the king had already done penance is mentioned, but in a confused way with reference to the previous council of 860, while the shortcomings of Queen Theutberga are dwelt upon at much greater length: 'How could she be joined in marriage, whom by her own assertion her brother did not fear to defile? ${ }^{22}$ Like Text A, Text $\mathrm{C}$ cites the council of Lerida, but strangely mislabels it as the council of Agde, whose proper canon it simply omits. Above all, the account appears to anticipate potential criticism both of the decision and of the procedure, rebutting it forcefully in the extended conclusion quoted above (p. 000) that is entirely absent from the other version.

In 1981, Nikolaus Staubach brilliantly demonstrated that Text A must be the version of Bishop Adventius of Metz, a key figure at Lothar's court. ${ }^{23}$ The attribution was based partly on vocabulary and citations, and partly on the textual transmission, that is to say on the single manuscript in which the text is preserved, Rome, Biblioteca Vallicelliana MS I 76. All the texts in this early modern transcription seem to have been written by Adventius, whether in

\footnotetext{
${ }^{22}$ Concilia Karolini Aevi IV, ed. Hartmann, p. 76: 'Quomodo enim posset matrimonio copulari, quam iuxta suam assertionem frater non pertimuit constuprare?'

${ }^{23}$ N. Staubach, Das Herrscherbild Karls des Kahlen: Formen und Funktionen monarchischer Repräsentation im früheren Mittelalter (Münster, 1981), esp. pp. 153-214.
} 
his own name or on behalf of someone else. The lost manuscript of which the Vallicelliana transcription is a copy was, it seems, a kind of portable archive that was put together for Bishop Adventius perhaps around 868 or even $869 .{ }^{24}$

As for Text C, which has an entirely separate manuscript transmission, Staubach convincingly suggested in the same book and elsewhere that this might be Archbishop Gunthar of Cologne's version of the Aachen Council. ${ }^{25}$ This proposal was again based partly on vocabulary and citations, but Staubach also pointed out that Text C's manuscript also contained two letters connected to, and probably written by, Gunthar. Staubach did not however look at this manuscript as a whole in the same way he did for the Vallicelliana transcription; but if we examine it more closely, this manuscript too provides valuable clues that change our understanding of both text and wider context.

\section{Vatican Pal. Lat. 576}

The manuscript in question is Vatican Biblioteca Apostolica Pal. Lat. 576, written in neat Carolingian minuscule, $20 \mathrm{~cm}$ by $28 \mathrm{~cm}$. The standard catalogue dates it to the tenth century, but the great palaeographer Bernhard Bischoff thought it could equally have been written in the ninth century; nor was he sure of its origins, merely attributing it, tentatively, to a scribe associated with or near to Rheims. ${ }^{26}$ Its contents are as follows:

\begin{tabular}{|l|l|l|}
\hline 1. & Fols 1-1v & List of the six general councils \\
\hline 2. & Fols 2-11 & Two letters by Hraban Maurus \\
\hline 3. & Fols 11-13v & Two joint letters by a number of bishops \\
\hline
\end{tabular}

\footnotetext{
${ }^{24}$ For further discussion, see C. West, 'Knowledge of the past and the judgement of history in tenthcentury Trier: Regino of Prüm and the lost manuscript of Bishop Adventius of Metz', EME 24 (2016), $137-59$.

${ }^{25}$ Staubach, Herrscherbild, pp. 181-7; N. Staubach, 'Sedulius Scottus und die Gedichte des Codex Bernensis', Frühmittelalterliche Studien 20 (1986), pp. 549-98, at pp. 564-5.

${ }^{26}$ E Stevenson and I.B. de Rossi, Codices Palatini Latini Bibliothecae Vaticanae (Rome, 1866), pp. 190-1; B. Bischoff, Katalog der festländischen Handschriften des neunten Jahrhunderts, vol. III (Wiesbaden, 2014), no. 6544, p. 415: 'Reimser Kreis (?), IX./X. Jh'. It was owned by Mainz in the fifteenth century, but its previous history is not known. The manuscript can be consulted online at the Bibliotheca Palatina digital website http://digi.ub.uni-heidelberg.de/de/bpd/index.html (accessed November 2016).
} 


\begin{tabular}{|c|c|c|}
\hline 4. & Fols $13 v-18 v$ & Ebbo of Rheims's Apologeticum \\
\hline 5. & Fol 19-26 & A third letter by Hraban Maurus \\
\hline 6 & Fols 26v-36v & $\begin{array}{l}\text { Council of Soissons } 853 \text { and associated } \\
\text { material }\end{array}$ \\
\hline 7. & Fols 36v-39r & $\begin{array}{l}\text { Council of Aachen } 862 \\
\begin{aligned}- & \text { Text B (Lothar's complaint) } \\
- & \text { Text C (Gunthar of Cologne) }\end{aligned}\end{array}$ \\
\hline 8. & Fols 39v-50 & 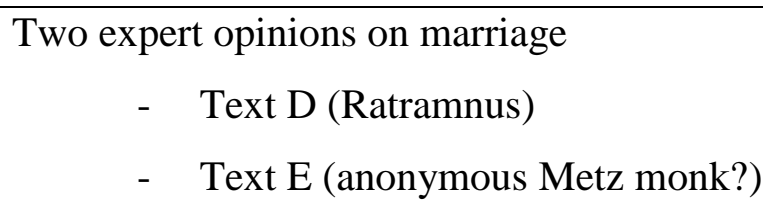 \\
\hline
\end{tabular}

Much of the manuscript is made up of material self-evidently related to King Lothar's attempt to end his marriage. In addition to Gunthar's Text C, it contains the text of Lothar's complaint that he brought to the 862 council (Text B), as well as two expert opinions on marriage (Texts D and E), one of which seems to have been written by the learned monk Ratramnus of Corbie in the wake of the council. ${ }^{27}$

As Staubach observed, the manuscript also contains two letters (no. 3) issued in the name of a number of bishops mostly from Lothar's kingdom, and probably written by Archbishop Gunthar. ${ }^{28}$ One of these letters, probably written in early 863 , was addressed to the bishops of East Francia, inviting them to consider the case of the bishop of Soissons, Rothad, who had been deposed by Hincmar of Rheims. The letter professes an open mind, but the steer is that Hincmar had acted illegitimately. The second letter, from March 863, is addressed directly to Hincmar, concerning his refusal to accept the appointment of Hilduin as bishop of Cambrai, a diocese in Lothar II's kingdom but in Hincmar's province. This letter is intemperate in tone, angrily attacking Hincmar for moral and legal transgressions, and demanding that he account for himself.

${ }^{27}$ These are edited as Texts B, D and E in Concilia Karolini Aevi IV, ed. Hartmann, pp. 74-5, 78-89. For the identification of Ratramnus, see now K. Ubl, Inzestverbot und Gesetzgebung: die Konstruktion eines Verbrechens (300 - 1100) (Berlin, 2008), p. 350.

${ }^{28}$ Concilia Karolini Aevi IV, ed. Hartmann, pp. 123-6 and pp. 132-5; Staubach, Herrscherbild, p. 182, n. 355 . 
Hostility to Hincmar is perhaps also reflected through the presence in the manuscript of two further texts, both relating to Archbishop Ebbo of Rheims. Ebbo had been deposed in 835 for his role in the rebellion against Emperor Louis the Pious, but was (temporarily) restored to his position in 840 , before being driven out again shortly afterwards. He was replaced by none other than Hincmar, whose own position as archbishop therefore depended on the validity of Ebbo's original deposition, and the invalidity of his short-lived restoration. ${ }^{29}$ Ebbo naturally saw things differently, and the Vatican manuscript contains the so-called Apologeticum, a text presenting Ebbo's point of view (no. 4). ${ }^{30}$ Werminghoff, who edited the text for the MGH, was unimpressed by the particular (and unique) arrangement of the work in the manuscript, because it does not seem to stick to chronological order, instead beginning with Ebbo's restoration before proceeding to his deposition. But what seemed to Werminghoff an ordo perversus may simply reflect an attempt to emphasise that 840 restoration; it may even be Ebbo's original arrangement. ${ }^{31}$

The need to counter Ebbo's arguments led Hincmar to organise the Council of Soissons in 853, whose acts are also copied in the Vatican manuscript (no. 6), along with Ebbo's original resignation text, extracts from a letter of Pope Benedict III that confirmed the synod and some explanatory material, forming a set that Hincmar disseminated to influence public opinion (exactly the same set can be found in Brussels, Bibliothèque Royale, 5413-22, ff. 5062, which once formed an independent quire). ${ }^{32}$ The council ruled in Hincmar's favour, at least according to the record that he himself made of it. But the issue did not go away, and in 860, anonymous figures at Lothar's court sought to integrate the Ebbo dispute into Lothar's divorce case, arguing that if Theutberga could not be removed from her marriage as a result of her public confession, so Ebbo could not have been deposed from his bishopric as a result of his. ${ }^{33}$ The presence in this manuscript of Hincmar's Soissons dossier, combined with Ebbo's Apologeticum in a form that stresses the legitimacy of his return in 840, suggests that

\footnotetext{
${ }^{29}$ See now R. Stone, 'Introduction', in Hincmar of Rheims. Life and Work, ed. R. Stone and C. West (Manchester, 2015), pp. 1-43.

${ }^{30}$ Concilia Karolini Aevi II, ii, ed. A. Werminghoff (Hanover, 1908), MGH, pp. 794-9.

${ }^{31}$ I am grateful to Steffen Patzold for advice here.

${ }^{32}$ Concilia Karolini Aevi III, ed. W. Hartmann (Hanover, 1984), pp. 264-79; Benedict's letter is in Epistolae Karolini Aevi IV, ed. Perels, pp. 367-8. For the Brussels manuscript, Hartmann, 'Original und Rekonstruktion', pp. 77-8.

${ }^{33}$ Stone and West, Divorce of King Lothar, pp. 11-12, 44.
} 
the compiler of this manuscript may have been familiar with that argument at least, and perhaps its mastermind.

As for the three letters written around 840 by the monk and sometime abbot of Fulda (and later archbishop of Mainz) Hraban Maurus that are copied into the manuscript, they are not found in this particular combination elsewhere and so we may assume were selected by the manuscript's compiler for some particular reason. ${ }^{34}$ It can hardly be a coincidence that the first two letters, to the chorbishop Reginbald and to Humbert of Würzburg, both deal with questions of marriage, and how it can be dissolved (no. 2). ${ }^{35}$ The first of these deals at length with incest as part of a wider set of questions; the second is devoted entirely to whether and how far incest acts as a bar to marriage. In general Hraban recommended a cautious, moderate approach: 'For if marriage were at once dissolved wherever any relatedness or kinship, even distant, can be found between the spouses, I fear that adultery and the crime of fornication would be multiplied' ${ }^{36}$

The third Hraban letter, addressed to Drogo of Metz and copied separately after Ebbo's apology on folios 19 to 26 (no. 5), concerns the status of assistant bishops known as chorbishops, whose position Hraban strongly defended against rising criticism. The details of diocesan hierarchies might not seem directly relevant to Frankish high politics of the 860 s, but what is interesting is how Hraban defended these clerics: he attacked 'certain western bishops' for destroying harmony, and criticised them at length for their vanity and pride, for which they were prepared to sacrifice ecclesiastical unity. ${ }^{37}$ Whoever Hraban originally had in mind with these words, it is not difficult to imagine the resonances of such a letter in Lothar's kingdom in the early 860s, and the place of this letter in the manuscript sandwiched between Ebbo's Apologeticum and Hincmar's 853 Council of Soissons - makes the point clear.

\footnotetext{
${ }^{34}$ R. Kottje, Verzeichnis der Handschriften mit Werken des Hrabanus Maurus (Hanover, 2012), p. 203. Kottje lists another letter of Hraban on fols $1-1 v$, but this seems to be an error.

${ }^{35}$ Epistolae Karolini Aevi III, ed. E. Dümmler (Berlin, 1899), MGH, nos. 30 (pp. 448-54, esp. 450-2) and 29 (pp. 444-8).

${ }^{36}$ Epistolae Karolini Aevi III, ed. Dümmler, p. 447: 'Si enim, ubicumque aliquid proximitatis vel consanguinitatis licet longinquae inter coniugatos inveniri potest, statim matrimonium dissolvitur, vereor, quod adulterium et fornicationis scelus multiplicetur' (fol. 10v of the Vatican manuscript). ${ }^{37}$ Epistolae Karolini Aevi III, ed. Dümmler, no. 25, ‘quidam ex occidentalibus episcopis’, p. 431.
} 


\section{Gunthar of Cologne}

Closer examination therefore shows that the short Vatican manuscript is coherent in its own terms. Every item can be connected to issues under intense discussion in Lothar II's kingdom in the early 860s: King Lothar's marriage, and the related standing of Archbishop Hincmar of Rheims, whose repeated interventions had not been welcomed by everyone. Staubach has already demonstrated that several of these texts can be connected with Gunthar. Looked at in the round, it seems likely the entire manuscript was a dossier, or a copy of a dossier, put together by or for the archbishop of Cologne. ${ }^{38}$ Given that every text seems to date from before the summer of 863 , we might suppose that this dossier was created in preparation for the ill-fated council of Metz in June 863, whose acts are unfortunately now lost.

If this reasoning is correct, there are two implications. The first is that we should not underestimate the capability of Archbishop Gunthar of Cologne. For Staubach, only Adventius of Metz was a strategist on a par with Hincmar, whose subtlety he greatly admired; the hot-headed and old-fashioned Gunthar, he implies, did not really even understand what he was up against. Yet though he probably owed his position to a distinguished family background, Gunthar was not necessarily intellectually outclassed by Hincmar. ${ }^{39} \mathrm{He}$ was a patron of Irish scholars, and it may for example have been his idea to apply Ambrosiaster's argument that men and women can be treated differently after marital separation to Lothar's case, since we know that there was a copy of Ambrosiaster's text in Cologne. ${ }^{40}$

\footnotetext{
${ }^{38}$ Bischoff's suggestion that the scribe might (he added a question mark) have been from 'the circle of Reims' does not mean that the manuscript was made there. The manuscript is not listed by F.M. Carey, 'The scriptorium of Reims during the archbishopric of Hincmar', in Classical and mediaeval Studies in honor of Edward Kennard Rand, ed. L. Jones (New York, 1938), pp. 41-60, and there is no indication that Hincmar knew all of its contents. Cologne scribes in the later ninth century did not have a recognisably distinct style: see L. Jones, The Script of Cologne from Hildebald to Herman (Cambridge, MA, 1932), p. 22, and the forthcoming survey of Cologne manuscripts on Anna Dorofeeva's project website, http://carolinenetwork.weebly.com (accessed November 2016) ${ }^{39}$ For Gunthar's background, S. Weinfurter, in Series Episcoporum Ecclesiae catholicae occidentalis, vol. V, Germania: Archiepiscopatus Coloniensis (Stuttgart, 1982), pp. 15-17.

${ }^{40}$ The Ambrosiaster manuscript is Cologne Dombibliothek 34, and the text is at f. 58v (the Codices Electronici Ecclesiae Coloniensis website, www.ceec.uni-koeln.de, accessed November 2016). The manuscript is usually dated to the tenth century but some experts have drawn attention to similarities
} 
And if we associate the Vatican manuscript as a whole with Gunthar, this helps explain an otherwise puzzling change of direction in arguments about King Lothar's marriage. Up to the council of Aachen in 862, the king's circle had concentrated on showing that Theutberga's alleged incest with her brother Hubert effectively annulled her marriage with Lothar. This argument, based on a tendentious interpretation of the decree attributed to the Council of Agde in 506, had been accepted (and perhaps even developed) by Hincmar of Rheims, who was not as unequivocally opposed to Lothar's divorce as is sometimes presumed. ${ }^{41}$ The only text likely to be associated with Adventius in the Vatican manuscript, edited as Text E, seems sympathetic to this line too. ${ }^{42}$ After April 862, however, the king suddenly switched to asserting instead that he had already been married to his mistress Waldrada before his marriage to Theutberga in 855 .

The reason for the shift was probably the realisation that the incest argument did not hold water. And that realisation would have dawned on anyone who read the Vatican manuscript: partly thanks to the devastating critique of Ratramnus's Text D, which pointed out that Theutberga's alleged incest had nothing to do with her marriage to Lothar; but also through Hraban's letters, which limit both the scope and the punishment of incest. ${ }^{43}$ Gunthar's association with the Vatican manuscript suggests therefore that far from being unable to compete on equal terms with wily Hincmar, he may have perceived the flaw in the incest argument earlier than anyone else. This might also explain why the Agde canon, cited in Adventius's version of the Aachen 862 council to legitimate the dissolution of incestuous

with ninth-century manuscripts, and it may not be a coincidence that this particular part of the manuscript has been carefully corrected. Cf. G. Vocino, 'A Peregrinus's Vademecum', in The Annotated Book. Early Medieval Practices of Reading and Writing, ed. M. Teeuwen and I. van Renswoude (Turnhout, forthcoming), on Bern Burgerbibliothek 363, a manuscript that Staubach associated with Gunthar's circle.

${ }^{41}$ See Stone and West, Divorce of King Lothar, pp. 62-4.

${ }^{42}$ Concilia Karolini Aevi IV, pp. 86-9, though the text breaks off because the copyist apparently gave up. The text is written to Bishop 'A.', most likely Adventius. We know that texts circulated within Lotharingia; given that it seems to respond to doubt, possibly this Metz text was disseminated as part of an internal struggle for public opinion, much like Hincmar circulated the acts of Soissons with an interpretative gloss.

${ }^{43}$ Concilia Karolini Aevi IV, pp. $78-86$. 
marriages, is missing from Gunthar's version of the council. He may have edited it out once he realised that it was at best irrelevant (if so, it would not be the last time that Gunthar tampered with synodal records). ${ }^{44}$

And it would explain too why it was Gunthar who subsequently championed the new line, that Lothar had already been married before he 'married' Theutberga. Though its plausibility was weakened by its belated appearance, this argument was intrinsically much stronger than the reliance on the council of Agde. It was theologically unassailable, since rules for entering marriage were less developed than rules for ending it, and Christian rules against bigamy were unambiguous; it was strategically safer too, since it made Lothar the key witness in his own case, rather than relying on Theuberga's forced self-incrimination. ${ }^{45}$

If the first implication of the Vatican manuscript concerns Gunthar's ability to mobilise eastern as well as western Frankish intellectual resources to negotiate church traditions, the second relates to Lothar II's court more broadly. That Lothar had not managed to unite his kingdom behind him is clear from many sources. ${ }^{46}$ Comparing the two accounts of the council of Aachen in 862, and placing these accounts in their manuscript context, sheds more light on this division. For to read the Vallicelliana and the Vatican manuscripts as sets of texts side by side suggests that Lothar II's two leading bishops pursued separate and contradictory strategies and tactics to resolve the challenges that faced the kingdom. While Adventius urged caution, and carefully covered his back by archiving his correspondence, Gunthar energetically moved things forward on his own initiative, though not without careful preparation and reflection.

To some extent this division may reflect to whom these figures turned for advice.

Adventius's closeness to Hincmar has already been remarked upon elsewhere, and it seems likely that he was a personal friend as well as imitator of the archbishop of Rheims (not least

\footnotetext{
${ }^{44}$ For Gunthar's treatment of the record of Metz 863, see Epistolae Karolini Aevi IV, ed. Perels, p. 347.

${ }^{45}$ Cf. Heidecker, Divorce, p. 103, n. 23, and pp. 130-1, for an alternative interpretation.

${ }^{46}$ On this division as fatal flaw, see S. Airlie, 'Unreal Kingdom: Francia Media under the shadow of Lothar II', in De la mer du Nord à la Méditerranée. Francia Media, ed. A. Dierkens, M. Gaillard, M. Margue and H. Pettiau (Luxembourg, 2011), pp. 339-56.
} 
in his archival practices); Gunthar by contrast not only fiercely attacked the archbishop in joint letters that Adventius conspicuously did not sign, but he also supported Hincmar's enemies (like Rothad of Soissons), associated with rivals like Archbishop Theutgaud of Trier (who provocatively claimed that he was technically Hincmar's superior), and sought opinions from those who, like Ratramnus of Corbie, were not always on friendly terms with the archbishop of Rheims. It is worth noting too that the man whose appointment as bishop of Cambrai Hincmar successfully blocked in 863, Hilduin, was apparently Gunthar's own brother; he was also a kinsman of Hincmar's own patron, Hilduin of St-Denis, which led Gunthar to accuse Hincmar of gross ingratitude. Gunthar's antipathy to the archbishop of Rheims may therefore have mixed the political with the personal. The Frankish Church had its tensions, and to some extent those tensions were manifested in the documentation of the events of 29 April 862.

\section{Conclusion}

Pope Nicholas's dramatic excommunication and deposition of Gunthar along with his colleague Theutgaud of Trier in October 863 plunged Lothar II's kingdom into a crisis from which it never recovered. But its remarkable impact cannot be credited simply to the pope's ambition and vision. After all, Nicholas on three occasions - twice in 864 and again in 867 summoned the Frankish bishops to Rome; they responded to this first-ever attempt by a pope to call a general council of the western church by simply not turning up. ${ }^{47}$ When he took such decisive action in 863 , Nicholas was putting his authority on the line. He must have calculated that it would crack Lothar's episcopate; and he was right, since the rest of Lothar's bishops, led by Adventius, dropped their former colleagues like a stone.

Examining the records of the council of Aachen in 862 gives us some clues as to why this was so. For Nikolaus Staubach, the whole council was a 'Schau-Veranstaltung', a meeting put on for show and not for the genuine discussion of the issues. ${ }^{48}$ If so, then its decision to permit two of its participants to prepare an independent record was all the more revealing: it suggested that the participants could not agree on the representation, let alone the procedure, something almost unprecedented in the Frankish church and a sign of profound division, despite Gunthar's attempts to cover it up. And when these records are placed back in their

\footnotetext{
${ }^{47}$ H. Sieben, Die Konzilsidee des lateinischen Mittelalters (847-1378) (Paderborn, 1984), pp. 39-41.

${ }^{48}$ Staubach, Herrscherbild, p. 183.
} 
manuscript context, it is possible to get a clearer sense of how this inability to agree on a common script seems to have reflected a divergence in strategic, tactical and perhaps personal priorities amongst Lothar II's leading advisers: a divergence of which Pope Nicholas took full advantage.

In this way, study of the Aachen council of 862, and above all of its records, exemplifies two themes that have been inspirationally explored by Rosamond McKitterick in many of her publications to date: on the one hand, the thorough penetration of Frankish society under the rule of the Carolingian kings by the structures and values of Christianity, to the extent that politics and religion are difficult to disentangle (and nowhere is that more true than in the matter of Lothar II's divorce); and on the other, the importance of not relying solely on modern editions of texts, no matter how scrupulous these may be, but of also returning to the surviving manuscripts for clues about their scribes and authors, and about the wider society that these scribes and authors were trying to change through their books. 